\title{
Inovasi Pelayanan Perizinan Bangunan Gedung 3.0 Di Pemerintah Provinsi Dki Jakarta
}

\author{
Gitta Sonali Kusuma Wardani \\ Fakultas IImu Administrasi, Universitas Indonesia \\ Email: gittasonalikusuma@gmail.com \\ Amy Yayuk Sri Rahayu \\ Fakultas Ilmu Administrasi, Universitas Indonesia \\ Email: amy_soeroso@yahoo.com
}

\begin{abstract}
Innovation has advanced fast not only in the private sector, but also in the public sector. One of public sector innovations in the field of licensing services in DKI Jakarta Provincial Government is Building Licensing Innovation 3.0 carried out by the Investment Agency and One Stop Integrated Services - DKI Jakarta Provincial Government. The objective of the 3.0 innovation is to speed up the process of completing a building permit (IMB), from 42 working days to 2-3 hours. This study used qualitative research approach with a descriptive research design to provide a clearer and deeper picture of a symptom or phenomenon occured. The data were obtained using observation, interviews, and literature studies with reference to the concept of public service innovation by Windrum (2008). The results indicated that the innovation of building permit services 3.0 in DKI Jakarta Provincial Government is a series of other forms of public sector innovation, although according to the process it does not run simultaneously and the forms of these innovations influence other forms of public sector innovation.
\end{abstract}

Keywords: Innovation, Service, Licensing 3.0, Building Construction Permit, DKI Jakarta

\begin{abstract}
Abstrak
Inovasi telah berkembang begitu luas bukan hanya terjadi di sektor swasta, namun juga digunakan di sektor publik. Salah satu contoh inovasi sektor publik di bidang pelayanan perizinan di Pemerintah Provinsi (Provinsi) DK Jakarta yakni Inovasi Perizinan Bangunan Gedung 3.0 yang dilakukan oleh Dinas Penanaman Modal dan Pelayanan Terpadu Satu Pintu - Pemerintah Provinsi DKI Jakarta. Tujuan inovasi 3.0 tersebut untuk mempercepat proses penyelesaian Izin Mendirikan Bangunan (IMB) yang selama ini dikeluhkan oleh masyarakat karena awalnya dalam menerbitkan IMB memerlukan waktu 42 hari kerja, namun saat ini hanya diperlukan waktu 2-3 jam saja. Penelitian ini merupakan penelitian kualitatif dengan pendekatan deskriptif untuk memberikan suatu gambaran yang lebih jelas dan mendalam mengenai suatu gejala atau fenomena yang terjadi. Sumber data penelitian ini menggunakan data primer dan sekunder yakni observasi, wawancara dan studi literatur dengan merujuk pada konsep inovasi pelayanan publik yang dikemukakan oleh (Windrum, 2008). Hasil studi ini menunjukkan bahwa inovasi izin perizinan pelayanan gedung 3.0 di Pemerintah Provinsi DKI Jakarta merupakan sekumpulan rangkaian dari bentuk-bentuk inovasi sektor publik lainnya walaupun menurut prosesnya tidak berjalan secara simultan dan bentuk dari inovasi ini saling mempengaruhi bentuk inovasi sektor publik lainnya.
\end{abstract}

Kata kunci: Inovasi, Pelayanan, Perizinan 3.0, Izin Mendirikan Bangunan, DKI Jakarta

\section{PENDAHULUAN}

Saat ini inovasi telah berkembang begitu luas bukan hanya terjadi di sektor swasta, namun juga digunakan di sektor publik. Menurut (Valkama, Bailey, \& Anttiroiko Veikkio, 2013) adanya perubahan global dan berbagai tantangan yang dihadapi oleh ilmuwan dan organisasi sektor publik mempengaruhi segala aktivitas inovasi yang dilakukan di sektor publik. Banyak alasan mengapa inovasi sektor publik harus dilakukan. Menurut studi Purwadi dkk (2020) menemukan bahwa inovasi di sektor publik yang dilakukan oleh Pemerintah China, 
didorong oleh rasa ketidakpuasan yang datang langsung dari Pemerintah China sendiri, bukan dari masyarakat.

Dalam konteks ini, inovasi sektor publik akan difokuskan pada inovasi pelayanan publik, terpatnya inovasi pada pelayanan perizinan. Perizinan adalah keputusan Tata Usaha Negara yang dibuat sepihak artinya dari pemerintah yang ditujukan kepada masyarakat yang memiliki argumentasi bahwa pemerintah sebagai pelaksana kedaulatan rakyat dapat memberikan keputusan atau tidaknya perizinan sesuai dengan aturan yang berlaku (Prasojo, Maksum, Epakartika, \& Kurniawan, 2007). Perizinan dapat menjadi alat bagi pemerintah daerah maupun pemerintah pusat untuk melaksanakan pembangunan dari mulai proses perencanaan, pengawasan hingga sampai evaluasi. Salah satu perizinan yang berkaitan erat dengan tata ruang terutama dalam pembangunan adalah Izin Mendirikan Bangunan (IMB). Pendirian bangunan berkaitan erat dengan penataan kota, karenanya IMB tak hanya penting untuk mempertegas keselamatan pengguna bangunan tapi juga penting dalam menciptakan kota yang nyaman dan indah sesuai dengan kaidah tata ruang yang berlaku. Selain itu, IMB juga digunakan untuk menjamin keandalan bangunan, keamanan dari pemilik bangunan dan lingkungan sekitarnya serta mengatur pemanfaatan ruang dengan baik (Herea \& Ungureanu, 2018).

Mengurus IMB merupakan salah satu indikator dalam penilaian Ease of Doing Business (EODB). EODB adalah indeks yang dibuat oleh World Bank terhadap kemudahan berusaha di 190 negara. Penilaian dilakukan terhadap 10 (sepuluh) indikator dalam memulai bisnis di suatu negara yang terdiri dari memulai usaha (starting a business), mengurus Izin Mendirikan Bangunan (dealing with construction permits), penyambungan listrik (getting electricity), pendaftaran properti (registering property), akses perkreditan (getting credit), perlindungan terhadap investor minoritas (protecting minority investors), pembayaran pajak (paying taxes), perdagangan lintas batas (trading across borders), penegakan kontrak (enforcing contracts) dan penyelesaian perkara kepailitan (resolving insolvency). Pada tahun 2019, Indonesia mengalami kenaikan hanya 1 level menjadi 73 dari tahun sebelumnya. Sementara pada waktu tahun 2018 Indonesia bisa naik hingga 19 peringkat dari 91 ke posisi 72. Hal ini masih jauh dari target Presiden Joko Widodo diranking 40 (Rencana Kerja Pemerintah, 2019).

Dari sisi indikator mengurus Izin Mendirikan Bangunan (IMB) (dealing with construction permits),
Indonesia mengalami penurunan 4 (empat) peringkat di tahun 2019, dimana Indonesia menduduki peringkat 112 dari 190 negara, sedangkan di tahun 2018, Indonesia menduduki peringkat 108 (Doing Bussiness, 2018). Hal ini mengindikasikan bahwa masih terjadi kesenjangan atau gap antara harapan pelanggan akan pelayanan IMB dengan pelayanan aktual yang diterima oleh pelanggan dalam pengurusan IMB atau dengan kata lain kualitas pelayanan dalam pengurusan IMB belum mengalami perubahan yang signifikan terutama di Jakarta sebagai bobot penilaian EODB terbesar dibandingkan Surabaya sebanyak $78 \%$.

IMB adalah perizinan yang diberikan oleh Pemerintah Daerah sebelum aktivitas pembangunan, perubahan serta perluasan terhadap bangunan dilakukan kepada pemilik bangunan sesuai dengan persyaratan administrasi dan teknis yang berlaku sehingga IMB menjadi penting dalam penyelenggaraan bangunan dan berakibat langsung pada penataan kota. Penyelenggaraan IMB di wiayah Jakarta diatur dalam Peraturan Gubernur No. 147 Tahun 2018 tentang Pelayanan Perizinan dan Non Perizinan Penyelenggaraan Bangunan Gedung. Klasifikasi IMB terbagi menjadi 4 (empat) jenis sesuai dengan tingkat kewenangannya sesuai dengan Pergub No. 47 Tahun 2017 tentang Petunjuk Pelaksanaan PTSP:

Tabel 1. Klasifikasi Izin Mendirikan Bangunan (IMB) di DKI Jakarta

\begin{tabular}{|c|c|}
\hline $\begin{array}{l}\text { Klasifikasi } \\
\text { IMB }\end{array}$ & Deskripsi \\
\hline $\begin{array}{l}\text { Tipe A } \\
\text { Provinsi }\end{array}$ & $\begin{array}{l}\text { - IMB Bukan Rumah } \\
\text { Tinggal dengan jumlah } \\
\text { lantai lebih dari } 8 \text { lantai } \\
\text { - IMB Pondasi }\end{array}$ \\
\hline $\begin{array}{l}\text { Tipe B } \\
\text { Kota/Kab } \\
\text { upaten } \\
\text { Administr } \\
\text { asi }\end{array}$ & 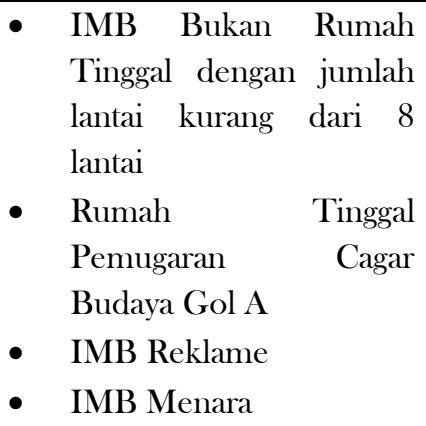 \\
\hline $\begin{array}{l}\text { Tipe C } \\
\text { Kecamata } \\
\mathrm{n}\end{array}$ & $\begin{array}{l}\text { - IMB Rumah Tinggal } \\
\text { dengan luas tanah } \geq 100 \\
\mathrm{~m}^{2}, \text { kondisi tanah tidak } \\
\text { harus kosong sampai } 3 \\
\text { lantai termasuk Cluster }\end{array}$ \\
\hline
\end{tabular}




\begin{tabular}{|l|l|}
\hline $\begin{array}{c}\text { Klasifikasi } \\
\text { IMB }\end{array}$ & \multicolumn{1}{|c|}{ Deskripsi } \\
\hline & • Pemugaran Cagar Budaya \\
& Gol B dan C \\
& - IMB Gudang dengan luas \\
& tanah kurang dari 1500 $\mathrm{m}^{2}$ \\
& dan maksimal 2 lantai \\
& - IMB Bukan Rumah \\
& Tinggal tidak mengubah \\
& konstruksi akan tetapi \\
& fungsi \\
\hline \multirow{3}{*}{ Tipe D } & IMB Rumah Tinggal luas \\
Kelurahan & tanah kurang dari atau \\
& sama dengan 100 m² \\
& kondisi tanah yakni kosong \\
& atau bangunan tua yang \\
& akan dihilangkan dan \\
& jumlah 2 lantai \\
\hline
\end{tabular}

Sumber: Peraturan Gubernur DKI Jakarta No. 47 Tahun 2017 tentang Petunjuk Pelaksanaan PTSP

Masih ditemukannya keluhan terhadap pelayanan perizinan di DKI Jakarta menunjukkan bahwa kualitas pelayanan yang diberikan belum sepenuhnya memenuhi harapan dari pemohon sehingga masih terdapat gap atau kesenjangan dan perlu adanya perbaikan (Setyawan, 2017). Selain itu, dari sisi pelaksanaannya masyarakat juga masih menemukan kesulitan untuk memenuhi persyaratan pengajuan IMB yang situasional (Bismakuncara \& Inayati, 2019). Masih banyaknya kendala dalam upaya peningkatan kualitas pelayanan seperti sumber daya manusia dan sarana serta prasarana penunjang pelayanan menunjukkan bahwa pelayanan publik masih dinilai belum optimal (Oktariyanda, Zauhar, \& Rochmah, 2013).

Salah satu upaya peningkatan kualitas pelayanan publik yang dilakukan Pemprov DKI Jakarta di bidang perizinan adalah melakukan terobosan baru khususnya pada pelayanan IMB yakni Perizinan Bangunan Gedung Selesai dalam 3 Jam (IMB 3.0).

Penelitian ini dilakukan untuk mengetahui bagaimana pelaksanaan inovasi Perizinan Bangunan Gedung Selesai dalam 3 Jam (IMB 3.0) di Provinsi DKI Jakarta.

\section{METODE PENELITIAN}

Penelitian ini merupakan penelitian kualitatif dengan pendekatan deskriptif untuk memberikan suatu gambaran yang lebih jelas dan mendalam mengenai suatu gejala atau fenomena yang terjadi. Sumber data penelitian ini menggunakan data primer dan sekunder yakni observasi, wawancara dan studi literatur. Teknik analisis dengan menggunakan 4 (empat) tahapan antara lain pengumpulan data, reduksi data, penyajian data, dan penarikan kesimpulan (Huberman \& Miles, 1983). Waktu penelitian ini dilakukan dibagi 2 (dua) periode yaitu penelitian literatur yang dilakukan mulai Mei-Juli 2020. Kemudian untuk penelitian lapangan dilakukan dalam waktu 2 minggu pada awal bulan Agustus 2020 di Dinas Penanaman Modal dan PTSP Provinsi DKI Jakarta dengan narasumber sebagai berikut:

- Bapak A, sebagai Kepala Subbagian Tata Usaha Pusat Data dan Informasi PMPTSP Provinsi DKI Jakarta

- Bapak B, sebagai Kepala Unit PMPTSP Kelurahan

- $\quad$ Ibu A, sebagai masyarakat yang mengurus IMB $3 \mathrm{Jam}$

- Bapak D, sebagai masyarakat yang mengurus IMB $3 \mathrm{Jam}$

\section{HASIL DAN PEMBAHASAN \\ Inovasi Pelayanan Publik}

Inovasi memiliki arti luas. Menurut pendapat yang dikemukakan oleh (Rogers, 1995) inovasi merupakan adopsi hal-hal baru dari ide atau gagasan, praktik, atau objek baru yang dilakukan oleh seseorang atau kelompok organisasi tertentu. Selain itu menurut (Knox, 2002) inovasi adalah suatu hal yang lebih luas dari apa yang sudah dimiliki sekarang sehingga kapabilitas individu atau organisasi bisa meningkatkan daya saing daripada dengan produk lainnya (value of superior to customer). Menurut Greenberg dan Baron dalam (Riyadi, 2019) bahwa inovasi merupakan hasil nyata keberhasilan dari sebuah pemikiran atau gagasan berdasarkan kreativitas sekelompok orang pada suatu organisasi. Secara umum dapat ditarik kesimpulan bahwa inovasi adalah hal-hal baru yang berasal dari ide atau gagasan kreatif untuk dipersepsikan secara baru baik oleh individu atau kelompok serta diimplementasikan untuk meningkatkan daya saing dengan produk lainnya.

Menurut (Windrum, 2008) ada 6 bentuk inovasi sektor publik antara lain sebagai berikut:

- Inovasi pelayanan, suatu bentuk inovasi oleh organisasi publik yang terdapat pada suatu produk/jasa, dapat berbentuk produk fisik maupun non fisik.

- Inovasi deliveri pelayanan, suatu bentuk inovasi yang dilakukan untuk menyampaikan pelayanan publik, bentuknya yakni bukan produk fisik 
melainkan sesuatu yang bisa dirasakan oleh pelanggan.

- Inovasi administrasi dan organisasi, suatu bentuk inovasi didalam struktur, system, prosedur pada suatu organisasi. Bentuk ini merupakan perubahan paling dasar atau sebagian dari sisi internal organisasi

- Inovasi konsep, suatu bentuk inovasi yang merupakan gagasan awal atau persepsi dalam rangka membuat organisasi lebih baik. Biasanya inovasi ini terkait dengan visi, misi, sasaran dan strategi organisasi.

- Inovasi kebijakan, suatu bentuk inovasi dari adanya kebijakan yang akan dating dan saat ini terjadi. Biasanya, inovasi ini dilihat dari peraturan atau instrument kebijakan lainnya yg sudah ada.

- Inovasi sistemik ialah bentuk inovasi dimana cara-cara organisasi melakukan hubungan kerjasama dengan organisasi lainnya baik itu sektor publik maunpun privat.

Berdasarkan keenam inovasi sektor publik diatas, ada 3 bentuk inovasi yang hasil atau outputnya bukan produk, melainkan hasil yang bisa dirasakan yakni pada inovasi deliveri pelayanan, inovasi administrasiorganisasi, dan inovasi sistemik sehingga dapat dibuat nama baru dan aktivitas yang dilakukan atas inovasi tersebut.

\section{Matriks Inovasi Sektor Publik}

Windrum (2008) mengatakan ada 2 (dua) bentuk inovasi di bidang pelayanan publik yaitu inovasi produk pelayanan (barang dan jasa) dan inovasi menyampaikan/deliveri produk (barang dan jasa). Kedua inovasi ini dapat berupa satu rangkaian maupun hal yang terpisah atau berbeda baik konsep maupun praktiknya. Selain itu, keempat bentuk inovasi lainnya yakni inovasi konsep, inovasi kebijakan, inovasi administrasi/organisasi dan inovasi sistematik dapat dilakukan sebelum ke tahap inovasi pelayanan publik yang artinya ada tahapan yang harus dilalui sebelum ke tahap inovasi pelayanan publik yang langsung bersentuhan dengan masyarakat. Hasil studi Asmara \& Rahayu (2019) mengemukakan bahwa keempat inovasi tersebut tidak harus dijalankan secara bersamaan, satu atau dua bentuk inovasi saja sudah bisa dan tidak harus melalui tahapan yang linear. Sebagai prasyarat, inovasi pelayanan publik harus melalui bentuk inovasi baik itu administrasi dan organisasi, konsep, kebijakan dan sistemik yang dilakukan oleh organisasi publik, hal tesebut menunjukkan bahwa organisasi sektor publik memiliki aturan dan tata kelola yang kaku.

Asmara \& Rahayu, (2019) menambahkan bahwa dalam internal organisasi dilatarbelakangi oleh inovasi konsep, yang kemudian didukung oleh perubahan kebijakan sebelum adanya perubahan organisasi dikarenakan berjalannya organisasi membutuhkan regulasi atau produk kebijakan. Selain itu, eksternal organisasi juga mendapatkan dampak langsung maupun tak langsung dari keempat inovasi yang dilakukan, biasanya perubahan-perubahan tersebut menghasilkan kerjasama antara baik sesama organisasi publik maupun pihak swasta atau privat.

Pada area publik/pengguna layanan, kedua inovasi produk/pelayanan dan inovasi deliveri pelayanan muncul. Inovasi ini dapat berupa perubahan teknis hasil dari berbagai inovasi yang terjadi di organisasi publik, yang terjadi bisa hanya berupa masing-masing inovasi produk pelayanan atau deliveri pelayanan atau keduanya bisa saling terkait. Inovasi ini tidak dapat terlaksana dengan baik tanpa adanya inovasi di internal organisasi. Selain itu, masyarakat juga akan terkena dampang langsung yang bisa memberikan masukan baik di area ini sendiri maupun di area internal organisasi.

Area terakhir yaitu eksternal organisasi dan publik, dimana tidak ada bentuk inovasi yang terjadi. Area ini juga dapat memberikan masukan terkait bentuk inovasi di internal organisasi serta eksternal organisasi yang sering kali menjadi faktor utama yang mendasari perubahan. Keempat area ini dipengaruhi oleh lingkungan yang terdiri dari aspek sosial, politik, ekonomi, teknologi, budaya dan berbagai peraturan baik nasional maupun internasional. Lingkungan juga dapat mempengaruhi tekanan bagi organisasi secara langsung dalam melakukan inovasi sesuai permintaan dan kebutuhan.

Dampak dari inovasi sektor publik ini juga berpengaruh terhadap lingkungan yang kurang bisa diukur secara spesifik karena aspek lingkungan yang secara cepat terjadi perubahan.

\section{Pelayanan Izin Mendirikan Bangunan (IMB)}

Menurut Mindarti \& Juniar (2018:22) pelayanan publik ialah "suatu usaha yang dilakukan oleh seseorang, kelompok atau institusi untuk memberikan pelayanan atau melayani keperluan orang lain dengan mendahulukan kepentingan publik diatas kepentingan pribadi maupun kelompok sebagai upaya untuk pemenuhan kebutuhan penerima layanan, mempermudah urusan publik. Dalam pelaksanaannya harus memberikan kepuasan kepada publik”. 
Salah satu pelayanan publik yang menjadi fokus dari studi ini ialah pelayanan izin mendirikan bangunan (IMB). Penyelenggaraan bangunan gedung adalah kegiatan pembangunan yang terdiri dari proses rencana teknis dan pelaksanaan konstruksi, serta kegiatan pemanfaatan, pelestarian, dan pembongkaran. Apabila melihat dari alur pembangunan izin mendirikan bangunan terletak pada perencanaan teknis dan bukan terletak pada pelaksanaan konstruksi atau setelahnya. Menurut Spelt dan Berge dalam (Trianti, 2017) berpendapat bahwa izin merupakan suatu persetujuan dari penguasa berdasarkan undang-undang atau peraturan pemerintah untuk dalam keadaan tertentu menyimpang dari ketentuan larangan perundangundangan, dengan catatan bahwa izin diberikan sebelum adanya aktivitas sehingga izin mendirikan bangunan diberikan sebelum adanya aktivitas konstruksi. Sedangkan menurut Hadjon dalam Melanie (2012) izin merupakan persetujuan dari penguasa berdasarkan peraturan yang ditetapkan dalam keadaan tertentu yang memungkinkan pemohonnya untuk melakukan kegiatan yang sebelumnya dilarang (tidak diizinkan) sehingga perlu adanya pengawasan khusus.

Izin Mendirikan Bangunan (IMB) merupakan sebuah rangkaian prosedur yang dinamakan Perizinan Konstruksi Bangunan atau Dealing with Construction Permit, hal ini tidak hanya melibatkan pemerintah akan tetapi juga masyarakat serta lembaga-lembaga non-pemerintah World Bank (2019). Berikut ini adalah tahapan-tahapan yang perlu dilalui dalam mengajukan IMB di Jakarta yaitu:

- Meminta surat pra-persetujuan dari otoritas penataan ruang

- Terima inspeksi dari otoritas penataan ruang

- Menerima surat pra-persetujuan dari otoritas penataan ruang

- Meminta dan mendapatkan salinan sertifikat Kepemilikan Tanah yang diaktakan

- Pengajuan izin lingkungan

- Pengajuan Izin Mendirikan Bangunan (IMB)

Makna ini lebih luas dibandingkan dengan definisi dari IMB itu sendiri, karena IMB merupakan salah satu tahapan untuk mendapatkan perizinan bangunan.

\section{Inovasi Pelayanan Perizinan di Pemerintah Provinsi DKI Jakarta}

Inovasi sektor publik di bidang pelayanan perizinan baik dalam inovasi pelayanan dalam bentuk produk atau jasa dan juga inovasi penyampaian pelayanan yang langsung dirasakan manfaatnya oleh pengguna. Sejak tahun 2015 terbentuknya Badan Pelayanan Terpadu Satu Pintu yang saat ini berubah nomenklatur menjadi Dinas Penanaman Modal dan PTSP (DPMPTSP). Sejak tahun 2015 DPMPTSP juga berhasil melakukan penyederhanaan perizinan dengan memangkas 222 izin dari 518 jenis izin, dilanjutkan pada tahun 2016 menjadi 476 jenis izin dan Agustus tahun 2017 menjadi 269 jenis izin, serta tahun 2018 menjadi dibawah 200 jenis perizinan yang diharapkan memuaskan masyarakat dalam mengurus perizinan.

Hingga saat ini DPM dan PTSP sudah melakukan berbagai inovasi di bidang pelayanan perizinan sebagaimana gambar berikut:

\section{Gambar 1. Berbagai Inovasi DPMPTSP}

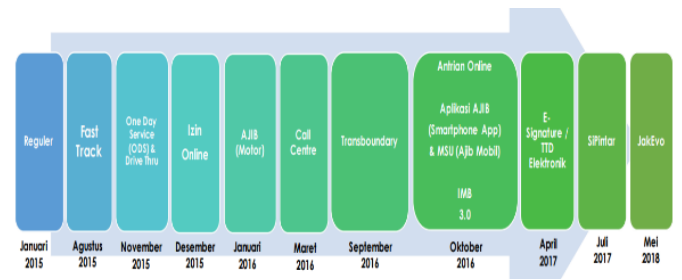

Sumber: Dinas Penanaman Modal dan PTSP

Pelayanan kantor PTSP berjumlah sebanyak 316 service point/unit pelayanan terdiri dari 267 kelurahan, 42 kecamatan, 5 kota, 1 kabupaten, 1 di provinsi. Berbagai inovasi yang sudah dibuat agar memudahkan masyarakat untuk menjangkaunya dan lebih mendekatkan pelayanan kepada masyarakat. Inovasi yang sudah dibuat antara lain: AJIB (Antar Jemput Izin Bermotor) melalui inovasi ini masyarakat dilayani antar jemput berkas perizinan, cukup dengan order melalui telepon di 1500164 pemohon tanpa perlu datang ke service point. Transboundary yakni inovasi dengan melakukan pelimpahan kewenangan hingga 2 tingkat struktur dibawahnya sehingga perizinan dapat diajukan ke unit terdekat dengan lokasi pemohon. Contohnya, mengurus SIUP TDP Besar yang tadinya menjadi kewenangan tingkat Kota, melalui transboundary pemohon dapat melakukan pengajuan di tingkat kecamatan. E-Signatur yakni inovasi melengkapi perizinan dengan full secara online dan izin bisa dicetak oleh pemohon secara mandiri. Jak-Evo yakni pernerbitan SIUP dan TDP dengan cepat secara simultan hanya dengan waktu 1 jam, IMB 3.0 yakni penerbitan IMB rumah tinggal 2 lantai dengan penyelesaian waktu paling lama 3 jam, dan lain sebagainya.

Inovasi Perizinan Gedung 3.0 dalam Perspektif Matriks Inovasi Sektor Publik 
Salah satu contoh inovasi sektor publik dibidang pelayanan perizinan di DKI Jakarta yakni Inovasi Perizinan Bangunan Gedung Selesai dalam 3 Jam (IMB 3.0) yang dilakukan oleh Provinsi DKI Jakarta tepatnya pada Dinas Penanaman Modal dan Pelayanan Terpadu Satu Pintu. Inovasi ini diluncurkan sejak tanggal 11 Agustus 2016 dan setahun kemudian pada tahun 2017 sudah menerbitkan sebanyak 719 IMB. IMB 3.0 termasuk inovasi pelayanan publik dengan bentuk inovasi pelayanan menghasilkan suatu produk yaitu IMB khususnya rumah tinggal. Berikut alur pembuatan IMB 3.0 diawali dengan pemohon melakukan permohonan sesuai dengan persyaratan sampai nantinya di proses melalui tim teknis administrasi, tim teknis lapangan, tim teknis pemeriksa, Kasubag Tata Usaha dalam menyetujui draft output IMB dan terakhir yakni pengesahan oleh Kepala Unit.

\section{Gambar 2. Alur pembuatan IMB 3.}

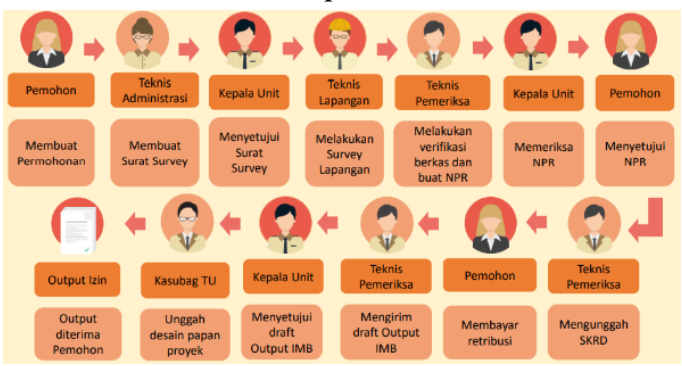

Sumber: Dinas Penanaman Modal dan PTSP

IMB 3.0 merupakan inovasi pelayanan publik dengan kategori cara penyampaian/deliveri pelayanan pengurusan IMB dalam waktu 3 jam. Artinya, Pemprov DKI telah melakukan upaya untuk memberikan pelayanan khususnya IMB kepada masyarakat untuk mempercepat proses penyelesaian IMB yang selama ini dikeluhkan oleh masyarakat dengan memangkas waktu penyelesaiannya yang awalnya memerlukan waktu 42 hari kerja, namun saat ini hanya diperlukan waktu 3 jam. Selain itu, tujuan munculnya konsep inovasi ini agar perkembangan kota menjadi lebih terpantau, keterbukaan informasi publik, kinerja SKPD yang lebih terintegrasi dan perizinan semakin mudah untuk dilakukan pengawasan.

Inovasi konsep muncul pertama kali dari Kepala Dinas Penanaman Modal dan PTSP yang ingin secara cepat merespon kebutuhan masyarakat terhadap penerbitan IMB. Masih adanya keluhan dari masyarakat dalam proses pengukuran Ketetapan Rencana Kota (KRK) sehingga menghambat proses pembuatan IMB. Sebagai komitmen dari pelayanan, konsep ini direspon oleh para pimpinan lainnya dan tim teknis dengan penyempurnaan melalui aplikasi yang bisa dilakukan dari smartphone yang dikenal dengan JakEvo, sehingga pemohon dapat mengurus izinnya sendiri tanpa bantuan calo. Pemohon juga bisa dilakukan dengan cara menerbitkan KRK dan IMB secara simultan dikarenakan peta operasional sudah terintegrasi dengan aplikasi pada komputer. Proses pembuatan KRK, saat ini juga sudah dilakukan secara daring, sehingga memudahkan masyarakat untuk dapat mengurusnya serta dengan cepat dapat dilanjutkan ke IMB. Sebelum adanya e-KRK, pembuatan KRK menghabiskan waktu 21 hari, namun saat ini proses pembuatan KRK menjadi 21 hari.

Tabel 2. Perbandingan Rata-rata Waktu Pemrosesan KRKS

\begin{tabular}{|c|c|c|}
\hline Kegiatan & $\begin{array}{c}\text { Tanpa Aplikasi } \\
\text { e-KRK }\end{array}$ & $\begin{array}{c}\text { Dengan Aplikasi } \\
\text { e-KRK }\end{array}$ \\
\hline \multicolumn{3}{|l|}{ Proses: } \\
\hline Registrasi Front Office & 1 hari & 10 menit \\
\hline Verifikasi Back Office & 7 hari & 5 menit \\
\hline Persetujuan Kepala Unit & 3 hari & menit \\
\hline Penjadwalan \& Survei & 7 hari & 300 menit \\
\hline Penomoran Tata Usaha & 2 hari & menit \\
\hline Penyerahan SK Dokumen & 1 hari & menit \\
\hline $\begin{array}{l}\text { Total Waktu } \\
\text { Penyelesaian }\end{array}$ & 21 hari & $\begin{array}{c}330 \text { Menit } \\
\text { (1 hari) }\end{array}$ \\
\hline
\end{tabular}

Sumber: Dinas Penanaman Modal dan PTSP

Inovasi konsep diturunkan menjadi inovasi kebijakan melalui tahap perumusan hingga tahap implementasi dari sisi penyedia layanan yakni Dinas Penanaman Modal dan PTSP. Inovasi kebijakan yang dilakukan oleh pimpinan mendorong seluruh unit PTSP pada tingkat kecamatan sebanyak 44 unit dan kelurahan sebanyak 267 unit untuk memberikan kontribusi terhadap penerbitan IMB melalui SK Kepala Dinas Penanaman Modal dan PTSP Nomor 70 Tahun 2016. Adapun persyaratan pengajuan IMB sebagai berikut:

- Dilakukan oleh pemohon langsung (tidak boleh dikuasakan) kecuali memiliki hubungan keluarga dibuktikan dengan fotokopi kartu keluarga

- Lahan yang ingin dibangun adalah lahan kosong

- Memiliki sertifikat tanah atas nama pemohon

- Terdiri dari 1 lahan kepemilikan saja

- Peruntukan sebagai rumah tinggal

- Hanya berlaku dengan luas tanah $<200 \mathrm{~m}^{2}$ dan luas bangunan yang direncanakan $<200 \mathrm{~m}^{2}$

- Untuk bangunan 1-2 lantai

- Desain bangunan mengikuti format yang tersedia

- Ketentuan kegiatan yang diizinkan, diizinkan bersyarat, maupun diizinkan terbatas sesuai Perda DKI No.1 Tahun 2014 
Adapun pengecualian untuk merasakan inovasi ini yakni:

- Tidak berlaku jika lokasi berada di zona hijau

- Tidak berlaku jika lokasi berada di pemugaran

- Tidak berlaku jika lokasi berada pada jalan/gang yang sulit dijangkau kendaraan bermotor

- Tidak berlaku jika peruntukkan rumah kontrakan /kost

- Tidak berlaku jika diketahui terdapat sengketa tanah

- Tidak berlaku jika adanya perbedaan peta lokasi dan peta operasional

Persyaratan dan ketentuan yang harus dipenuhi terkadang menjadi halangan bagi masyarakat untuk merasakan inovasi ini. Lahan yang ingin dibangun adalah lahan kosong dan desain bangunan yang harus mengikuti format yang tersedia menjadi persyaratan dengan penolakan terbesar dari pengajuan berkas melalui inovasi ini.

Inovasi kebijakan ini telah berdampak secara langsung terhadap perubahan administrasi dan organisasi di Dinas Penanaman Modal dan PTSP terutama pada Unit PM dan PTSP seluruh Kecamatan dan Kelurahan. Pada sisi internal organisasi, banyak terjadi perubahan yang mendukung terhadap berjalannya inovasi di bidang pelayanan perizinan. Walaupun tidak semua proses secara administrasi dan struktur organisasi berubah, akan tetapi ada perubahan kecil dan cukup mendasar yang berpengaruh terhadap munculnya berbagai inovasi di DPMPTSP. Salah satu inovasi administrasi dan organisasi yang muncul yakni adanya tim teknis pada masing-masing Unit PM dan PTSP Kecamatan dan Kelurahan. Selain itu adanya Tim Pengembangan Inovasi pada Dinas Penanaman Modal dan PTSP yang bekerja untuk menemukan masalah-masalah dan cara penyelesaiannya melalui inovasi tersebut. Adanya keterbatasan jumlah tim teknis yang terdiri dari PNS maupun Non PNS oleh karena itu, Dinas Penanaman Modal dan PTSP merekrut tenaga ahli untuk saling melengkapi dalam berinovasi tanpa meninggalkan tugas utama mereka melayani perizinan.

Inovasi kebijakan juga mendorong munculnya inovasi sistemik. Inovasi perizinan bangunan gedung ini melibatkan Lembaga Sandi Negara terkait penerapan penandatanganan secara elektronik pada hasil akhir dokumen IMB. Selain itu adanya kerjasama dengan Balai Sertifikasi Elektronik terkait pemanfaatan sertifikat elektronik, dan juga adanya kerjasama dengan Dinas Kependudukan dan Pencatatan Sipil DKI Jakarta terkait sinkronisasi data pemohon berdasarkan Nomor Induk Kependudukan (NIK). Hubungan lainnya adalah menjalin kerjasama dengan Dinas Komunikasi, Informatika dan Statistik DKI Jakarta dalam hal keamanan jaringan dan collocation server. Melalui tanda tangan secara elektronik dan QR Code hal ini memberikan kemudahan untuk melacak dokumen dan kemudahan untuk SKPD yang melakukan pengawasan izin karena diberikan tembusan produk izin secara cepat sesuai dengan masing-masing wilayah.

Inovasi administrasi organisasi dan inovasi sistemik ini juga mempengaruhi inovasi kebijakan dimana pimpinan pada DPM dan PTSP memberikan kesempatan untuk tim teknis maupun tim pengembangan inovasi untuk melakukan berbagai kegiatan dan kerjasama dengan pihak lain untuk mendukung inovasi di PTSP. Adapun kerjasama juga dilakukan dengan Dinas Kominfotik terkait pengelolaan e-Government. Hal ini juga dapat dijadikan sebagai input terhadap bentuk inovasi sistemik yang berjalan dan juga memiliki dampak pada inovasi administrasi organisasi administrasi organisasi seperti pembagian sistem kerja antara inovasi pelayanan publik dengan tugas utamanya yakni melayani perizinan.

Pengaruh dari organisasi eksternal dan publik ditunjukkan dengan semakin banyaknya berbagai kegiatan inovasi lainnya yang dilakukan oleh Dinas Penanaman Modal dan PTSP seperti munculnya inovasi perizinan gedung lainnya seperti Program IMB dengan Jasa Arsitek Gratis yakni inovasi yang memudahkan masyarakat DKI Jakarta untuk membangun rumah tinggal dengan menggunakan jasa arsitek secara gratis dan secara khusus dilengkapi dengan model sketsa unik khas Betawi. Selain itu, pada tahun 2019 muncul juga E-KRK (ElektronikKetetapan Rencana Kota yakni aplikasi elektronik untuk penerbitan KRK dalam waktu penyelesaian 1 (satu) hari kerja dengan menggunakan aplikasi online dan tandatangan elektronik. Dalam membuat e-KRK masyarakat cukup melengkapi persyaratan melalui aplikasi tanpa harus datang ke unit PTSP. Dampak lain yang ditimbulkan oleh inovasi ini yakni masyarakat tidak perlu membuang waktu sebanyak 42 hari, hanya dengan waktu 3 jam saja, pengurusan izin IMB sudah dapat diselesaikan, tak heran jika DPMPTSP mendapatkan penilaian dari masyarakat atau sering disebut dengan Indeks Kepuasan Masyarakat (IKM) sebesar 83,03.

\section{PENUTUP}

Simpulan 
Inovasi Perizinan Bangunan Gedung Selesai dalam 3 Jam (IMB 3.0) merupakan salah satu dari sekian inovasi yang ada di pelayanan perizinan. Inovasi ini merupakan sekumpulan rangkaian dari bentuk-bentuk inovasi lainnya walaupun menurut prosesnya tidak berjalan secara simultan dan bentuk dari inovasi ini saling mempengaruhi bentuk inovasi lainnya. Inovasi konsep yang muncul dari pimpinan dengan tujuan untuk mempercepat proses perizinan telah diterima masyarakat, kemudian inovasi kebijakan dengan adanya Surat Keputusan Kepala Dinas dan persyaratan dan pengecualian proses perizinan IMB 3 Jam, lahan kosong dan mengikuti desain yang sudah ditentukan menjadi halangan bagi banyak masyarakat untuk merasakan inovasi ini. Selanjutnya, inovasi administrasi organisasi yakni munculnya Tim Teknis pada masing-masing Unit PTSP dan Tim Pengembangan Inovasi pada tingkat Dinas. Masih terbatasnya jumlah tim teknis dalam menjalankan inovasi ini menjadi tantangan tersendiri bagi Dinas Penanaman Modal dan PTSP Pemerintah Provinsi (Pemprov) DKI Jakarta. Inovasi sistemik yakni adanya hubungan kerjasama dengan Lembaga Sandi Negara dan Balai Sertifikasi Elektronik, Dinas Kependudukan dan Pencatatan Sipil serta Dinas Komunikasi, Informatika dan Statistik DKI Jakarta dalam menghasilkan suatu produk pelayanan yakni output atau berkas Izin Mendirikan Bangunan dan adanya produk izin secara digital dapat mempercepat pelacakan dokumen serta pemberian dokumen kepada SKPD pengawas izin. Selain itu, pengaruh dari organisasi eksternal dan publik membuat Dinas Penanaman Modal dan PTSP selalu beraktivitas untuk menghasilkan inovasi-inovasi baru terutama terakit pelayanan perizinan demi menjadi solusi perizinan warga Jakarta serta pengaruh dari publik yakni adanya penilaian kepuasan masyarakat yang baik sebesar 83,03.

\section{Saran}

Dinas Penanaman Modal dan PTSP Pemerintah Provinsi (Pemprov) DKI Jakarta dapat mensosialisasikan kepada masyarakat terkait persyaratan dan pengecualian pengurusan IMB serta melakukan rekrutmen tenaga teknis eskternal baik dari antar satuan kerja di lingkungan Pemprov DKI Jakarta maupun dari luar instansi Pemprov DKI Jakarta, misalnya dengan melakukan pembayaran kontrak kepada tim teknis swasta.

\section{DAFTAR PUSTAKA}

Asmara, A. Y., \& Rahayu, A. Y. S. (2019). Inovasi Pelayanan Kesehatan Gancang Aron Di Kabupaten
Banyuwangi Dalam Perspektif Matrik Inovasi Sektor Publik. JPSI (Journal of Public Sector Innovations), 3(2), 57.

Bismakuncara, O., \& Inayati, I. (2019). Evaluasi Program Izin Mendirikan Bangunan Dengan Jasa Arsitek Gratis Bagi Rumah Tinggal (Studi Pada Dinas Penanaman Modal Dan Pelayanan Terpadu Provinsi DKI Jakarta). Jurnal Manajemen Pelayanan Publik, 2(2), 116.

Detik. (2018). Detik. Retrieved from https://news.detik.com/berita/d-4335947/pemprovdki-luncurkan-layanan-imb-online

Bank, World. (2018). Doing Business 2018, Reforming to Create Jobs. USA: Washington DC

Herea, V., \& Ungureanu, E. (2018). Building Permits, Definition, Legal Regulations. Sectia: Technical University of Iasi.

Huberman, A., \& Miles, B. M. (1983). Drawing Valid Meaning from Qualitative Data: Some Techniques of Data Reduction and Display. Quality and Quantity.

Knox. (2002). Understanding Your Management Style. Lexington Books Ans Imprint of Macmilan, Inc.

Mindarti, Lely Indah \& Juniar, Aryn Pratista Azaria. (2018). Inovasi Layanan Kesehatan Berbasis EGovernment (Studi pada Puskesmas Kecamatan Kepanjen Kabupaten Malang). Journal of Public Sector Innovations 3 ( 1): 19 - 27.

Oktariyanda, T. A., Zauhar, S., \& Rochmah, S. (2013). Pelayanan Izin Mendirikan Bangunan (IMB) dalam Mencapai Kualitas Pelayanan Publik yang Optimal. Jurnal Wacana Sosial dan Humaniora, Pascasarjana UB, 16(4), 179-185.

Purwadi, P., Asmara, A.Y., Nashihuddin, W., Pradana, A., Dinaseviani, A., \& Jayanthi, R. (2020). Inovasi Pelayanan Publik di China: Suatu Pembelajaran bagi Pemerintah dalam Peningkatan Layanan Publik di Indonesia. Jurnal Administrasi Dan Kebijakan Publik, 5(1), 86-113. https://doi.org/10.25077/jakp.5.1.86-113.2020

Prasojo, E., Maksum, I. R., Epakartika, I., \& Kurniawan, T. (2007). Deregulasi dan Debirokratisasi Perizinan di Indonesia. Depok: Depok: Departemen Ilmu Administrasi FISIP UI. 
Riyadi, M. K. (2019). Inovasi Sistem Manajemen Kinerja Sdm Terintegrasi Dengan Big Data Di Bpjs Kesehatan. JURISMA : Jurnal Riset Bisnis \& Manajemen, $9(1), 35-44$.

Rogers, E. M. (1995). Diffusion of Innovations (Fourth Edition). New York: USA: The Free Press.

Setyawan, I. P. B. (2017). Analisis Kinerja Pelayanan Publik (Studi Kasus Pada Pelayanan One Day Service Dinas Penanaman Modal Dan Pelayanan Terpadu Satu Pintu Provinsi DKI Jakarta). Universitas Indonesia.

Trianti, D. A. (2017). Pelaksanaan Pemberian Izin Pinjam Pakai Kawasan Hutan Untuk Pengadaan Jalan Di Jalur Lintas Selatan Di Wilayah Kabupaten Blitar. Universitas Muhammadiyah Malang.

Valkama, P., Bailey, S. J., \& Anttiroiko Veikkio, A. (2013). Organizational Innovation in Public Services Forms and Governance. UK: Palgrave Macmillan.

Windrum, P. (2008). Innovation and Entrepreneurship in Public Services. In Paul Windrum and Per Koch (Eds.), Innovation in Public Sector Services: Entrepreneurship, Creativity and Management. Cheltenham: UK: Edward Elgar. 